http://journal.unj.ac.id/unj/index.php/jpud

Volume 12 Edisi 2 November 2018

JURNAL PENDIDIKAN USIA DINI

DOI: https://doi.org/10.21009/JPUD.122

DOI: https://doi.org/10.21009/JPUD.122.20

\title{
IMPLEMENTASI MARKET DAY DALAM MENGEMBANGKAN ENTREPRENEURSHIP ANAK USIA DINI DI TKIT AN-NAJAH KABUPATEN ACEH TENGAH
}

\author{
Zulkarnain', Eliyyil akbar ${ }^{2}$ \\ Sekolah Tinggi Agama Islam Negeri, Gajah Putih Takengon Aceh Tengah, Aceh \\ zul.3lathif@gmail.com ${ }^{1}$, elayakbar@yahoo.co.id ${ }^{2}$
}

\begin{abstract}
ABSTRAK
This research discussed the market day activities to improve children entrepreneurship of TKIT Sunnah An-Najah of Central Aceh and to find out entrepreneurial value of the students. This is descriptive field research. It used three data collection methods, including observation, interview, and documentation. To make the market day activities easier to understand, the researcher divided them into three processes: planning, application, and assessment. Furthermore, the application of having those students get into entrepreneurial value also involves fostering the values of entrepreneurship before and after the market day activity. The values desired are bravery, selfconfidence, independence, good behavior, honesty, sense of appreciation, work commitment, discipline, cooperative and being communicative and oriented towards results. Through this observation, it is found that the conduction of the market day activities can help stimulate children's cognitive and socio-emotional growth, language skills, and physical-motor development.
\end{abstract}

Keyword: market day, entrepreneurship

Penelitian ini membahas kegiatan market day dalam mengembangkan entrepreneurship pada anak di TKIT Sunnah An-Najah Kabupaten Aceh Tengah dan untuk mengetahui nilai-nilai entrepreneurship yang ditanamkan pada anak dengan kegiatan market day di TKIT Sunnah AnNajah Kecamatan Bebesen Kabupaten Aceh Tengah. Jenis penelitian ini adalah deskriptif dengan menggunakan pendekatan field research yang dilaksanakan di TKIT Sunnah An-Najah Kabupaten Aceh Tengah. Teknik pengumpulan data yang digunakan adalah observasi, wawancara, dokumentasi. Implementasi kegiatan market day dalam mengembangkan entrepreneurship dilakukan dengan perencanaan, pelaksanaan serta penilaian. Pelaksanaan Kegiatan market day dalam mengembangkan entrepreneurship meliputi pra market day, saat market day serta pasca market day. Pelaksanaan entrepreneurship dapat mengembangkan aspek perkembangan kognitif, sosio-emosional, bahasa, dan fisik motorik anak dapat bertambah. Nilai-nilai entrepreneurship yang ditanamkan pada anak dengan kegiatan market day yaitu berani, pecaya diri, mandiri, santun, menghargai, jujur, berorientasi pasar, berorientasi tugas, berorientasi hasil, disiplin, kooperatif, komunikatif.

Kata kunci: market day, kewirausahaan

\section{PENDAHULUAN}

Seseorang yang memiliki jiwa entrepreneur memiliki kepribadian produktif, kreatif, inovatif, imajinatif, profesional, berani mengambil resiko, berani bertindak cepat, pekerja keras disiplin, ulet, gigih, rajin, energik, pekerja keras, berorientasi laba, menciptakan keunggulan, siap menerima resiko dan kerugian, bertindak ekonomis, optimis, percaya 
diri, tidak mudah menyerah. Sifatsifat tersebut dapat dibudidayakan sejak usia dini (Christianti, Cholimah, \& Suprayitno, 2015).

Data menunjukkan bahwa yang berhasil menjadi wirausaha di Indonesia adalah $1,65 \%$ dari jumlah penduduk saat ini, sedangkan Malaysia menduduki 5\% dan Thailand 4\% (Engel \& Susanto, 2017). Untuk menyamakan posisi Indonesia dengan negara maju dalam bidang ekonomi, perlu $2 \%$ wirausaha dari jumlah total penduduk (Asmani, 2011). Jumlah wirausaha yang selalu bertambah dapat meningkatkan taraf ekonomi negara, adanya lapangan pekerjaan serta kesejahteraan juga merambah pada individu sehingga dapat bersaing dalam pola kehidupan, dan selektif dalam dampak arus globalisasi.

Kenyataan yang ada, kecerdasan intelektual lebih diprioritaskan sehingga anak-anak mempunyai kecenderungan yang rendah dalam berkreativitas, yang mana anak kurang mampu menjelaskan idenya, rasa keingintahuan anak masih tergolong minim, imajinasi anak masih belum tereksplorasi, adanya ketidakberanian dalam mengambil resiko, dan sifat saling menghormati masih rendah (Yetti, Azizah, Coates, Carft, \& Duffy, 2017). Masalah tersebut dapat diminimalisir dengan cara memberikan pengenalan kepada anak tentang entrepreneurship sehingga layanan pendidikan dapat mengembangkan semua aspek perkembangan anak.

Layanan dalam pendidikan entrepreneurship menjadi agenda penting dalam membina serta memperbaiki kualitas individu. Layanan ini sebaiknya di mulai sejak dini yaitu pada usia emas (golden age). Pengenalan entrepreneurship dilakukan melalui kebiasaan dalam hal-hal yang bermakna sehingga menjadikan anak semakin cakap dalam kegiatan tersebut.

Nilai yang bisa dikembangkan untuk anak usia dini adalah mandiri, kreativitas, pengambilan resiko, berorientasi pada tindakan dan kemimpinan. Tahap kreatif dalam menumbuhkan jiwa entrepreneurship adalah tahap observasi, tahap berfikir, fase penemuan dan fase implementasi (Christianti et al., 2015). Tahapan tersebut merupakan dasar utama untuk mendapatkan peluang sukses sehingga dapat mampu menumbuhkan kreatifitas dan inovasi (Dearlina, 2013). Kreatifitas anak sebenarnya sudah muncul sejak pra masuk pada dunia pendidikan. Sebagaimana yang biasa dilakukan anak ketika bermain di rumah yaitu permainan yang menggunakan uanguangan, bermain jual-jualan serta bermain pasar-pasaran yang mana anak berperan seperti penjual dan pembeli. Adegan anak tersebut merupakan imajinasi yang muncul secara alami. Sebagaimana yang dijelaskan bahwa "Imagination 
Implementasi Market Day.....

Zulkarnain \& Eliyyil

always builds using materials supplied by reality" (Tsai, 2012).

TKIT An-Najah berupaya menjadikan anak lebih mandiri, lebih dapat membangun realitas serta mengenalkan anak tentang pendidikan entrepreneurship yaitu dengan kegiatan market day. Market day merupakan salah satu strategi pembelajaran yang digunakan untuk menanamkan sikap pengusaha pada anak-anak (Safitri, AE; Mukminin, 2017). Berdasarkan pengamatan di TKIT Sunnah An-Najah, dijumpai proses pembelajaran yang berbasis kewirausahaan karena pihak sekolah ingin menumbuhkan jiwa kewirausahaan pada diri anak sehingga muncul sifat jujur sebagaimana kegiatan tidak mengurangi sebuah timbangan karena hal tersebut tidak dianjukan dalam ajaran Islam. Uniknya di TKIT Sunnah An-Najah guru mengajarkan anak untuk membayar pada kasir kejujuran.

Aktifitas Market Day termasuk kegiatan yang bukan hanya menjadikan anak sebagai pengusaha namun membuat anak lebih mandiri, cakap. Market Day merupakan kegiatan yang dilakukan sebagaimana sistem jual beli yang sebahagian menjadi penjual bagi sebahagian yang lain. Pembelajaran ini termasuk dalam model pembelajaran berbasis pengalaman (Experiental learning). Anak memperoleh pembelajaran dan secara langsung mengalami melalui praktik-praktik nyata. Pembelajaran tersebut mempunyai orientasi terhadap kegiatan anak secara individu terkait pengalaman (Fathurrohman, 2015).

Kajian entrepreneurship sudah banyak dibahas namun fokusitas market day dalam mengembangkan entrepreneurship masih jarang dibahas khususnya untuk usia dini. Sebagaimana kajian yang dilakukan oleh Bakhti (2015) tentang upaya meningkatkan entrepreneurship anak melalui cooking class pada kelompok $\mathrm{B}$, yang bertujuan untuk mengetahui sejauh mana kegiatan cooking class dapat meningkatkan kewirausahaan pada siswa kelompok B1 TK Negeri Model Banyuwangi.

Metode penelitian tersebut adalah (PTK) penelitian tindakan kelas. Hasilnya adalah dari 3 kali kegiatan cooking class yang diamati, terlihat adanya peningkatan kewirausahaan pada anak. Pada kegiatan pertama diperoleh nilai ratarata 33,142 atau $51,78 \%$, pada kegitan ke 2 nilai rata-rata yang diperoleh sebesar 40,214 atau 62,89\%, sedangkan pada kegiatan ke 3 nilai yang diperoleh 43,285 atau 67,63\%.

Selain itu, kajian yang dilakukan oleh Khuluqo (2016) juga membahas mengenai cara membangun wirausaha warganegara Indonesia melalui lembaga pendidikan anak. Hasilnya adalah hal terpenting dalam proses pembelajaran adalah kesadaran akan kapasitas anak usia dini, pembelajaran yang menyenangkan dapat menjadi daya 
tarik dan efektif daripada menggunakan metode instruktif.

Perbedaan tulisan-tulisan ini sebagaimana kajian Ihsana (2016) memberikan sudut pandang pendidikan kewirausahaan anak usia dini yang digunakan membangun atau menjadikan sebagai pengusaha sedangkan penulis fokus kepada nilai kewirausahaan melalui market day. Kajian Wida fokus pada cooking class sedangkan kajian ini fokus pada market day. Cara yang berbeda namun untuk satu tujuan yaitu entrepreneurship.

Penelitian ini lebih dikerucutkan mengenai kegiatan market day dalam mengembangkan kewirausahaan pada anak di TKIT Sunnah An-Najah Kabupaten Aceh Tengah dan untuk mengetahui nilai-nilai kewirausahaan yang diberikan oleh guru terhadap anak dengan market day di TKIT Sunnah An-Najah Kecamatan Bebesen Kabupaten Aceh Tengah.

\section{Entrepreneurship}

Entrepreneurship sama dengan kewirausahaan. Kata entrepreneur asalnya dari bahasa Perancis, yaitu ientreprende yang artinya petualang (Anwar, 2014). Kegiatan wirausaha dapat dijalankan secara individu atau berkelompok. Wirausaha atau entrepreneur adalah seseorang yang penuh semangat dan energik serta pengambil resiko yang moderat (Supriyanto, 2014). Hal tersebut menunjukkan bahwa kewirausahaan (entrepreneurship) dan wirausaha (entrepreneur) memiliki perbedaan yang mana konsep kewirausahaan adalah sikap dan perilaku wirausaha sedangkan wirausaha yaitu seseorang yang memiliki daya cipta serta mampu mengembangkan suatu produk, sistem yang bernilai sebagai pencarian titik peluang dalam mewujudkan sebuah kesuksesan. Wirausaha dapat menjadikan seseorang untuk lebih beretika karena mengandung nilai-nilai yang bermakna. Nilai yang dikembangkan meliputi pertama olah pikir, nilai yang terkandung adalah daya cipta dan pengembangan ata inovasi, keingintahuan, berfikir kritis, produktif, mempunyai basis ilmu pengetahuan dan teknologi. Kedua, olah hati meliputi nilai berani mengambil resiko, percaya diri dan pantang menyerah. Ketiga, olah rasa meliputi nilai peduli, santun, rapi, nyaman, saling menghargai, toleran, dinamis, kerja keras dan beretos kerja. Keempat, olahraga meliputi nilai berorientasi pasar, berorientasi tugas, berorientasi hasil, kepemimpinan, disiplin, sportif, andal, kooperatif dan gigih (Ansori, 2012).

Kegiatan entrepreneurship
merupakan aktifitas yang
mempengaruhi kondisi seseorang
untuk mengubah cara berfikir dan
berperilaku sehingga menciptakan
sesuatu yang baru, berharga dengan
memanfaatkan usaha dan waktu
(Yetti et al., 2017). Entrepreneurship
yang dilakukan pada lembaga
pendidikan dapat dijadikan sarana

Kegiatan entrepreneurship merupakan aktifitas yang seseorang untuk mengubah cara berfikir dan berperilaku sehingga menciptakan sesuatu yang baru, berharga dengan (Yetic et al., 2017). Entrepreneurship yang dilakukan pada lembaga pendidikan dapat dijadikan sarana 
Implementasi Market Day.....

Zulkarnain \& Eliyyil

dalam memanfaatkan usaha dan waktu sehingga tercipta suasana hari yang menyenangkan bagi anak karena proses belajar anak sesuai realita. Realita kegiatan entrepreneurship untuk anak dapat membangun nilai kemandirian, kreativitas, pengambilan resiko; berorientasi pada tindakan dan kemimpinan (Christianti et al., 2015). Oleh karena itu, dalam merubah pikiran dan perilaku anak dapat terwujud melalui aktifitas yang melibatkan anak secara langsung.

\section{Market Day}

Market merupakan usaha kompleks untuk memenuhi kebutuhan berbagai kelompok dalam konteks regulasi untuk memastikan kualitas serta sarana aksesibilitas untuk belajar. Ciri khas pasar yaitu antara konsumen dengan penyedia layanan saling berinteraksi yang menghasilkan sesuatu yang bermanfaat (Snelson \& Deyes, 2016). Kegiatan market day dapat menjadikan anak untuk mendapatkan pembelajaran secara tidak konvensional namun secara partisipatif untuk meningkatkan keterampilan serta kemampuan anak.

Market day dapat diperoleh melalui aktivitas enterpreneur, yang mana anak belajar cara mengiklankan dagangannya kepada para konsumen (Suharyoto, 2017). Market day dapat berupa pembagian tugas sebagai pembeli dan penjual yang tidak terlepas dari seluruh pihak sekolah (guru, anak, orang tua) dan tidak menutup kemungkinan pembeli berasal dari luar pihak sekolah. Prepare untuk kegiatan ini bukan sepenuhnya guru yang merencanakan atau menyelenggarakan namun anak terlibat bersama guru dalam menyiapkan market day. Keterlibatan anak tentu membutuhkan ketergantungan dengan orang tua seperti anak di minta membawa hasil kebun, maka orang tua membantu anak menyediakan sesuai instruksi guru demi lancarnya kegiatan. Kegiatan market day di TKIT AnNajah yang menjadi pelaku penjual adalah anak, sedangkan pembeli berasal dari anak, orang tua dan guru.

\section{METODE PENELITIAN}

Metode tulisan ini deskriptif kualitatif (Moleong, 2002), dengan penelitian lapangan (field research) yang mempunyai tujuan mendalam tentang sosial sehingga terdapat hasil secara terorganisir. Penelitian dilakukan di TKIT Sunnah An-Najah, Kecamatan Bebesen Kabupaten Aceh Tengah. Sumber data ditentukan dengan teknik purposive sampling atau dengan pertimbangan tertentu.

Pengumpulan data dilakukan melalui, pertama pengamatan mengenai implementasi kegiatan market day dalam mengembangkan kewirausahaan pada anak di TKIT Sunnah An-Najah Kabupaten Aceh Tengah dan untuk mengetahui nilainilai wirausaha pada anak dengan kegiatan market day di TKIT Sunnah An-Najah Kecamatan Bebesen 
Kabupaten Aceh Tengah. Kedua, wawancara semiterstruktur yaitu dengan in-depth interview. Hasil wawancara diamati dengan cermat kemudian diidentifikasi dalam catatan. Ketiga, dokumentasi dilakukan dengan mengumpulkan bentuk tulisan yang meliputi data, RKH, kurikulum. Dokumentasi berbentuk gambar meliputi foto kegiatan market day. Data dikombinasikan dari berbagai sumber dan teknik pengumpulan data untuk menjaga kredibilitas data.

Analisa data menggunakan model Miles dan Huberman yaitu pertama menganalisis data meliputi data reduction dengan membuat rangkuman dari hasil wawacara, memilah pentingnya yang menjadi implementasi market day dan nilai entrepreneurship.

Kedua mendisplaykan data, membuat bagan, hubungan antar kategori. Ketiga membuat kesimpulan dengan menjawab implementasi market day dan nilai entrepreneurship.

\section{HASIL DAN PEMBAHASAN}

Kegiatan market day dalam mengembangkan kewirausahaan pada anak di TKIT Sunnah An-Najah Kabupaten Aceh Tengah dilakukan setiap semester sekali dan sebagai pembelajaran praktek berdagang. Sebagaimana yang dijelaskan oleh Ibu Mahyuni, pendidik di TKIT Sunnah An-Najah bahwa "Proses Penerapan pembelajaran kewirausahaan di sekolah dilakukan dengan sederhana yaitu mengenalkan anak pada nilai uang, mengenalkan konsep menabung serta bermain menirukan orang berjualan di pasar dan dilakukan melalui bermain peran dengan kegiatan market day. Misalnya anak-anak bermain peran sebahagian anak berperan sebagai pedagang dan sebahagian lagi anak berperan sebagai pembeli". Dari penjelasan tersebut bahwa kegiatan entrepreurship TKIT Sunnah AnNajah dilakukan dengan bermain peran.

Item perencanaan dalam pembelajaran entrepreneurship tertuang dalam perencanaan harian dalam kegiatan yang melibatkan perkembangan kognitif, logis matematis karena konsep berfikir kritis tersirat dalam pengamalan pembelajaran entrepreneurship. Sedangkan praktik entrepreneurship melalui market day termaktub dalam sebuah progam sekolah dalam setiap semester sekali. Item pelaksanaan kegiatan market day meliputi pra kegiatan, saat kegiatan serta pasca kegiatan yang bertujuan untuk kelancaran kegiatan.

Pra kegiatan market day dilakukan dengan memberikan pengetahuan tentang entrepreurship mulai dari pengurangan dan penjumlahan. Pengenalan tersebut dilakukan supaya anak memahami dan mengenal jumlah uang, misalnya para gura menyediakan gambargambar uang atau menunjukkan uang secara langsung pada anak, dan 
menyiapkan segala keperluan anak pada saat bermain peran. Ibu sa'diyah juga menjelaskan bahwa "Dalam menerapkan pembelajaran kewirausahaan pada anak tepatnya di lingkungan sekolah banyak yang bisa kita terapkan, misalnya saja yang paling sederhananya adalah dengan mengajak anak berhitung. Dengan berhitung anak akan mengenal dan memahami nilai dari suatu angka".

Selain itu, anak diajarkan untuk beretika dalam kegiatan market day. Sebagaimana yang dijelaskan bahwa "Melalui konsep yang sederhana ini anak dapat belajar mengenal uang dan cara berbisnis secara sederhana. Anak akan mulai memahami bahwa untuk memperoleh sesuatu, kita harus membeli terlebih dahulu dengan uang dan anak akan memahami sebagai pedagang akan mendapatkan uang hasil dari penjualan itu harus ada kerja keras yang dilalui untuk mendapatkan hasil yang maksimal. Selain itu konsep kejujuran sangat ditekankan pada anak ketika dalam proses jual beli”. Secara umum, cara yang digunakan guru dalam memberikan pengetahuan tentang intrepreneurship kepada anak adalah melalui cerita dan praktek. Cerita yang dilakukan adalah dengan memberi wawasan bahwa dengan kegiatan berdagang dapat menghasilkan sesuatu dari hasil dagangan. Praktek yang dilakukan adalah melakukan jual beli yang mana anak dilatih kejujuran karena bayar hasil pembelian diletakkan di kasir kejujuran.

Anak-anak yang menjadi pembeli diarahkan agar mereka mau mengantri dengan disiplin sebelum melakukan kegiatan market day. Budaya mengatri yang ditanamkan pada anak usia dini bertujuan untuk melatih anak untuk berprilaku tertib dan santun serta sabar dalam melakukan pekerjaan. Antri yang dicontohkan guru terdapat tujuan untuk mengembangkan kemampuan motorik anak, anak diarahkan untuk berbaris dengan dua barisan memanjang dan memegang pundak teman. Sebagaimana dapat dilihat dari gambar 1:

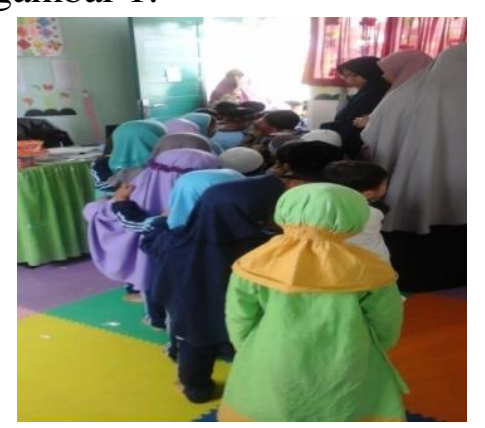

Gambar 1. Pra Kegiatan Market Day

Kegiatan market day akan memudahkan anak untuk memahami arti dari kejujuran serta untuk mendapatkan sesuatu yang bernilai harus dengan kerja keras yang didasari dari keikhlasan hati. Dengan membiasakan anak untuk dapat berinteraksi dengan kawan sehingga perkembangan sosial anak dapat meningkat. Begitu pula percakapan antara penjual dan pembeli sehingga perkembangan bahasa anak dapat meningkat. Sebagaimana dapat dilihat dari gambar 2: 


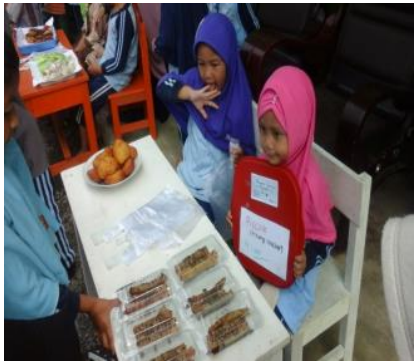

Gambar 2. Saat Kegiatan Market Day

Dari gambar di atas menunjukkan bahwa anak sedang mempromosikan barang dagangannya yaitu pisang coklat. Anak terlihat senang melakukan kegiatan tersebut, dalam pelaksanaan kegiatan market day tampak anak tampil dengan rasa percaya diri dalam menawarkan barang daganganya kepada anak yang lain. Selain itu, para guru mengajarkan anak untuk mau menawarkan barang dagangan dengan bahasa yang santun. Dari kegiatan market day ini bukan hanya dapat mengembangkan entrepreneurship namun juga mampu mengoptimalkan perkembangan anak seperti perkembangan kognitif, perkembangan sosio-emosional, perkembangan bahasa, dan perkembangan fisik motorik anak.

Uniknya kegiatan market day pada TKIT An-Najah, pembayaran bukan dilakukan langsung kepada penjual namun tersedianya tempat kasir kejujuran. Penerapan pembelajaran kewirausahaan dengan kegiatan market day dilakukan dengan membiasakan anak bersikap jujur. Sebagaimana yang disampaikan Ibu kepala sekolah "Saya meminta anak untuk melakukan pembayaran di tempat kasir yaitu dengan mengutamakan kejujuran. Anak akan memilih makanan yang dijual temantemannya yang lain lalu ia berjalan ke tempat kasir untuk proses pembayaran." Sebagaimana dapat dilihat dari gambar 3:

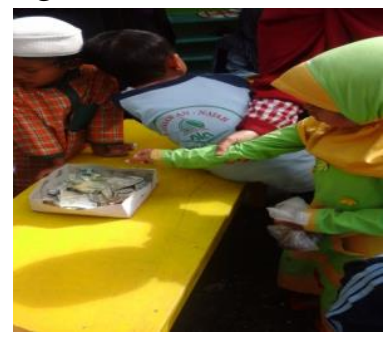

Gambar 3. Kasir Kejujuran

Dari gambar tersebut dapat tersirat bahwa guru sedang mendampingi anak untuk membayar secara mandiri di tempat kasir dengan mengutamakan nilai kejujuran. Hal tersebut mengajak anak untuk berpikir berapa uang yang harus dibayar atau berapa uang kembalian yang diambil.

Pasca kegiatan market day yaitu menghitung uang dan bersih-bersih yang dilakukan oleh anak. Anak-anak menghitung uang secara bersamaan (berhitung bersama), guru sebagai pemimpin. Anak-anak juga mengembalikan alat-alat yang digunakan untuk berjualan di tempat semula. Nilai wirausaha yang diberikan pada anak dengan market day di TKIT Sunnah An-Najah Kecamatan Bebesen Kabupaten Aceh Tengah yaitu:

a. Olah Pikir

Pengolahan daya pikir anak melalui kegiatan market day dapat mengembangkan intrepreneurship 
seperti berfikir sebagaimana cara menawarkan produk dagangan, produktif sebagaimana melakukan penjualan, berorientasi ilmu pengetahuan sebagaimana cara mengenal ilmu intrepreneur dan cara yang dilakukan pra kegiatan market day.

\section{b. Olah hati}

Pengolahan hati yang dilakukan pada kegiatan market day dalam mengembangkan intrepreneurship meliputi nilai berani, pecaya diri sebagaimana anak belajar berani untuk menjadi penjual dan berani untuk melakukan transaksi beli. Nilai keberanian dapat disimpulkan bahwa anak yang mampu menjadi seseorang yang tidak takut dan menjadi lebih percaya diri. Anak yang berani adalah anak yang mampu melakukan sesuatu tanpa ada rasa takut sehingga apabila anak ditanamkan keberanian sejak dini maka akan meningkatkan rasa percaya diri terhadap anak. Selain itu, olah hati pada kegiatan market day adalah mandiri yaitu tidak adanya sifat ketergantungan dengan orang dewasa.

\section{c. Olah rasa}

Pengolahan hati yang dilakukan pada kegiatan market day dalam mengembangkan intrepreneurship meliputi nilai santun sebagaimana cara anak berkomunikasi dengan calon pembeli dan menawarkan produk dagangan. Anak-anak yang dilatih untuk bersikap jujur maka akan terbiasa berbuat baik dalam kehidupan sehari-hari. Anak diajarkan jujur dalam memberitahu pembeli jika barang yang dijual rusak atau bagus serta anak diajarkan untuk berlaku jujur dalam pengambilan uang kembalian di tempt kasir.

d. Olah raga

Nilai pada olah raga adalah kooperatif sebagaimana yang dilakukan anak ketika pasca kegiatan yaitu melakukan penghitungan pemerolehan dari kasir kejujuran serta membersihkan lokasi dengan sama-sama. Selain itu, olahraga dalam kegiatan market day dalam mengembangkan intrepreneuship yaitu komunikatif yang mana terdapat pola interaksi melalui bahasa anak.

\section{KESIMPULAN}

Intrepreneuship yang diberikan kepada anak merupakan proses dalam membentuk mental berwirausaha karena bukan hanya mengajarkan anak terkait cara menjual dan membeli namun untuk meningkatkan nilai-nilai yang bermakna sehingga tertanam dan terpatri dan dapat diaktualisasikan dalam kehidupan kelak. Pembelajaran kewirausahaan bukan hanya diberikan kepada orang dewasa yang cukup mapan secara individu sebab untuk meningkatkan kualitas pribadi, namun dapat dilakukan dalam jenjang pendidikan seperti Taman Kanak-Kanak yaitu dengan cara yang menyenangkan dan dapat melalui kegiatan market day. Market day termasuk kegiatan yang dapat mengembangkan soft skill seperti keterampilan berwirausaha, kreatif, berani, bertanggung jawab 
dan lain sebagainya. Penerapan dan pengembangan keterampilan yang dilakukan sejak dini akan menjadi pondasi yang kuat bagi kemampuan kewirausahaan anak.

\section{DAFTAR PUSTAKA}

Ansori, M. et al. (2012). Pendidikan Karakter Kewirausahaan. Yogyakarta: Andi Offset.

Anwar, M. (2014). Pengantar Kewirausahaan. Jakarta: Kencana.

Asmani, J. . (2011). Sekolah Entrepeneur. Jakarta: Harmoni.

Bakhti, W. (2015). Upaya Meningkatkan Entrepreneurship Anak.

Christianti, M., Cholimah, N., \& Suprayitno, B. (2015). Development of Entrepreneurship Learning Model for Early Childhood, 3(3).

Dearlina, S. S. Y. (2013). Kewirausahaan. Medan: Perdana Publishing.

Engel, Y. A., \& Susanto, H. (2017). Pahlawan Ekonomi Kreatif. Jakarta: Gramedia.

Fathurrohman, M. (2015). Model-model Pembelajaran Inovatif. Yogyakarta: Ar-ruzz Media.

Khuluqo, I. E. L. (2016). Early childhood entrepreneurship education : a brief description of an ideal entrepreneurship learning for middle childhood, 818-827.

Moleong, L. J. (2002). Metodologi Penelitian Kualitatif. Bandung: Remaja Rosdakarya.

Safitri, AE; Mukminin, A. (2017). Learning Entrepreneurs Early Childhood to Increase the Attitude of Children's Children In Khalifah History Sukonandi Yogyakarta.
Snelson, S., \& Deyes, K. (2016). Understanding the Further Education Market in England, (296), 1-156.

Suharyoto, L. S. (2017). Menanamkan Nilai Kewirausahaan Melalui Kegiatan Market Day. Golden Age: Jurnal Pendidikan Anak Usia Dini, l(1).

Supriyanto, P. D. (2014). How to Become a Successful Entrepreneur. Yogyakarta: Andi Offset.

Tsai, K. C. (2012). Play , Imagination, and Creativity: A Brief Literature Review, 1(2),15-20. https://doi.org/10.5539/jel.v1n2p15

Yetti, E., Azizah, S. A., Coates, E., Carft, A., \& Duffy, B. (2017). Improved Creativity in Early Childhood through Entrepreneurship Education, 58, 399-403. 